\title{
Application of a distributed degree-day model of glaciers in the upper reaches of the Beida River Basin
}

\author{
Sheng Wang ${ }^{1} \cdot$ Jinfeng Wang ${ }^{2} \cdot$ Jianchen $\mathrm{Pu}^{3}$
}

Received: 8 April 2015/Accepted: 9 December 2015/Published online: 12 March 2016

(C) Springer-Verlag Berlin Heidelberg 2016

\begin{abstract}
Based on in-situ data of Qiyi Glacier from 2010 to 2012, a daily distributed degree-day model on a $90 \times 90 \mathrm{~m}$ grid was developed to simulate the spatial and temporal variations of the glacier mass balance, ELA, and meltwater run-off depth in the Beida River Basin from 1957 to 2012. In the model, different vertical lapse rates of temperature and precipitation gradients were used in different months and height-belts, and the influence of 'temperature jump' was also considered. The results indicated that the average annual mass balance and meltwater run-off depth of the glaciers in the Beida River Basin were $-93.3 \mathrm{~mm}$ w. e. and $443 \mathrm{~mm}$, respectively. Assuming a continuous linear trend, the ELA had risen by $505 \mathrm{~m}$ over 55 years. The mass balance linearly increased with the altitude in the cold season (Oct.-Apr.) and exponentially in the warm season (May-Sep.). The most possible abrupt change points of the mass balance, ELA, and meltwater run-off depth time series were all in 1992/93, as determined through the $\mathrm{M}-\mathrm{K}$ test. The mass balance turned increasingly negative since then, but the ELA and meltwater run-off increased rapidly. The climate sensitivity test showed that the air temperature was a dominant factor that
\end{abstract}

Sheng Wang

wangsheng@itpcas.ac.cn

1 Key Laboratory of Tibetan Environment Changes and Land Surface Processes, Institute of Tibetan Plateau Research, Chinese Academy of Sciences, Beijing 100101, China

2 Key Laboratory of Water Cycle and Related Land Surface Processes, Institute of Geographic Sciences and Natural Resources Research, Chinese Academy of Sciences, Beijing 100101, China

3 State Key Laboratory of Cryospheric Sciences, Cold and Arid Regions Environmental and Engineering Research Institute, Chinese Academy of Sciences, Lanzhou 730000, China affected the mass balance of the continental glaciers on the basin scale, which was different from the response mechanism of maritime glaciers. When the air temperature $\left(+1{ }^{\circ} \mathrm{C}\right)$ and precipitation $(+10 \%)$ increased simultaneously, the glacier mass loss and meltwater run-off reached $1.66 \times 10^{8} \mathrm{~m}^{3}$ and $2.45 \times 10^{8} \mathrm{~m}^{3}$, respectively.

Keywords Distributed degree-day model of glacier . Application - Mass balance - The Beida River Basin

\section{Introduction}

The glacier mass balance reflects the relationship between the income and expenditure of glacier mass (Cuffey and Paterson 2010). It not only has a direct effect on the glacier fluctuation and meltwater change, but it is also one of the most sensitive indicators of glaciers that reflect climate change (Young 1977; Wang and Zhang 1992; Yao et al. 2012). As important freshwater resources, variations in the glacier mass profoundly affect the water cycle, water resource utilization (Shi and Zhang 1995; Liu et al. 2006), the ecological environment in cold regions (Wang et al. 2001; Yang et al. 2004), and the sea level rise (Lemke et al. 2007; Cazenave et al. 2009; Pfeffer et al. 2008; Meier et al. 2007). Under the background of global warming, glacier mass balance studies have greater significance in assessing the contribution of glaciers to the sea level rise and exploring the relationship between the climate and glaciers.

The P-T, degree-day, and energy balance models are three common models for simulating the glacier mass balance. The $\mathrm{P}-\mathrm{T}$ model is a statistical method that requires a long time series of observations to determine parameters. The energy balance model can describe the physical processes of the glacier surface in detail, but the parameters 
and input data are not readily available due to observed restrictions. Thus, it is difficult to generalize the above two models. The degree-day model is based on the linear relationship between the glacier melt and air temperature. Because of the wide availability and easy interpolation of the air temperature data, the model is widely used in glacier mass balance simulations in locations including Northern Europe, the Greenland Ice Sheet, the Alps, and the Tibetan Plateau (Braithwaite and Zhang 2000; Liu et al. 1998; Jóhannesson et al. 1995; Reeh 1991; Zhang et al. 2006; Gao et al. 2010). Although the model calculation is simple, its simulated accuracy is even better than that of the energy balance model on the basin scale (Hock 2003). In the further development of the degree-day model, new physical variables are continually added, such as solar radiation, direct radiation, and albedo (Hock 1999; Arnold et al. 1996), and different degree-day factors are used for different glacier surface conditions (ice or snow) and topographic features (e.g., altitude, slope, aspect and terrain) (Zhang et al. 2005, 2006). Degree-day models have developed into a phase of distributed models (Braithwaite and Olesen 1993).

In arid and semi-arid regions, especially in Northwest China, glaciers are important freshwater resources (Barnett et al. 2005). According to the results of remote sensing monitoring, glaciers in the Beida River Basin had shrunk continuously since 1956 . The rate of the glacier area reduction was $14.3 \%$ (Liu et al. 2002), 15.4-18.7\% (Yan et al. 2012; Chen et al. 2013) and 29.6\% (Huai et al. 2014) during the periods of 1956-1990, 1956-2003 and 1956-2010, respectively. The estimates of the glacier mass balance in the Beida River Basin were few. Shen et al. (2001) estimated that the mass balance of glaciers in this basin was between 50-90 mm w. e. during 1956-1990. Insitu observation of glaciers is difficult to carry out due to numerous restrictions. Within the study area, Qiyi Glacier was the only glacier that had been observed for more than 10 years. The mass balance of Qiyi Glacier was positive in most years until the early 1990s, and had turned increasingly negative since then (Pu et al. 2005; Wang et al. 2011; Yao et al. 2012). The most negative mass balance of Qiyi Glacier was in 2005/06, with a value of $-955 \mathrm{~mm}$ w. e. (Yao et al. 2012). Variations of the equilibrium line altitude (ELA) of Qiyi Glacier had an upward trend during 1958-2008, with the highest ELA (5131 m) in 2005/06, and the ELA of Qiyi Glacier increased by $\sim 230 \mathrm{~m}$ in the past 50 years (Wang et al. 2010). As mentioned above, assessments of the glacier mass change mostly focused on the large scale (regional or global) (Meier 1984; Kaser et al. 2006; Meier et al. 2007; Yao et al. 2012; Gardner et al. 2013), with a few on the basin scale. In the Beida River Basin, variations in the glacier mass were closely related to local industry, agriculture and the sustainable development of the environment. In this paper, a distributed degree-day model with high temporal and spatial resolution $(1$ day, $90 \times 90 \mathrm{~m})$ was developed to reconstruct the glacier mass balance, ELA and meltwater run-off of the Beida River Basin during 1957-2012. The aim of this study was to clarify the characteristics of the spatial and temporal variation for the glacier mass balance, ELA, and meltwater run-off, discussing the response mechanism of glaciers to climate change and providing a scientific basis for forecasting future variations of glaciers and runoff.

\section{Study area}

The Beida River Basin $\left(97^{\circ}-99^{\circ} 30^{\prime} \mathrm{E}, 38^{\circ}-40^{\circ} \mathrm{N}\right)$ is located in the middle of the Hexi Corridor, Northwest China. It originates from the east of Taolainan Mountain in the Qilian Mountains and belongs to the western branch of Heihe River Water System (Fig. 1). According to the Chinese Glaciers Catalogue I-Qilian Mountains (Wang et al. 1981), the Beida River Basin has a total of 650 glaciers. The total area of the glaciers is $290.76 \mathrm{~km}^{2}$, with ice reserves of $10.37 \mathrm{~km}^{3}$. For the whole basin, the average altitude of the glacier terminals is $4430 \mathrm{~m}$, and the ELAs are between 4500 and $4850 \mathrm{~m}$. Under the effects of climate warming, the glaciers melted strongly, causing significant loss of ice from the surface of the glaciers and leading to a general increase in melt water run-off in the upper reaches of the Beida River Basin.

Qiyi Glacier $\left(39.5^{\circ} \mathrm{N}, 97.5^{\circ} \mathrm{E}\right)$ is the only glacier that has a long-term observed series in the Beida River Basin. It is located on the north slope of Tuolai Mountain in the middle of the Qilian Mountains, and its meltwater flows into the Liuquangou River, which is a branch of the upper Beida River. The scale of this glacier is small, with an area of only $2.76 \mathrm{~km}^{2}$. The altitude of the glacier terminal is $4304 \mathrm{~m}$, and its peak altitude is $5158.8 \mathrm{~m}$. According to the physical characteristics, Qiyi Glacier belongs to the sub-continental glacier type (Pu et al. 2005). The in-situ observations of Qiyi Glacier were inconsecutive. Observation began in 1958, and then some observation studies were carried out in 1975-1978 and 1985-1988. Semi-locating comprehensive observations have been recovered since 2000 .

\section{Data and methods}

\section{Data}

The datasets included meteorological data, in-situ observed data of Qiyi Glacier, topographic maps, Landsat TM images, and digital elevation models (DEM). Because of the 
Fig. 1 Sites of hydrometeorological and mass balance observations on Qiyi Glacier and glacier distribution in the Beida River Basin
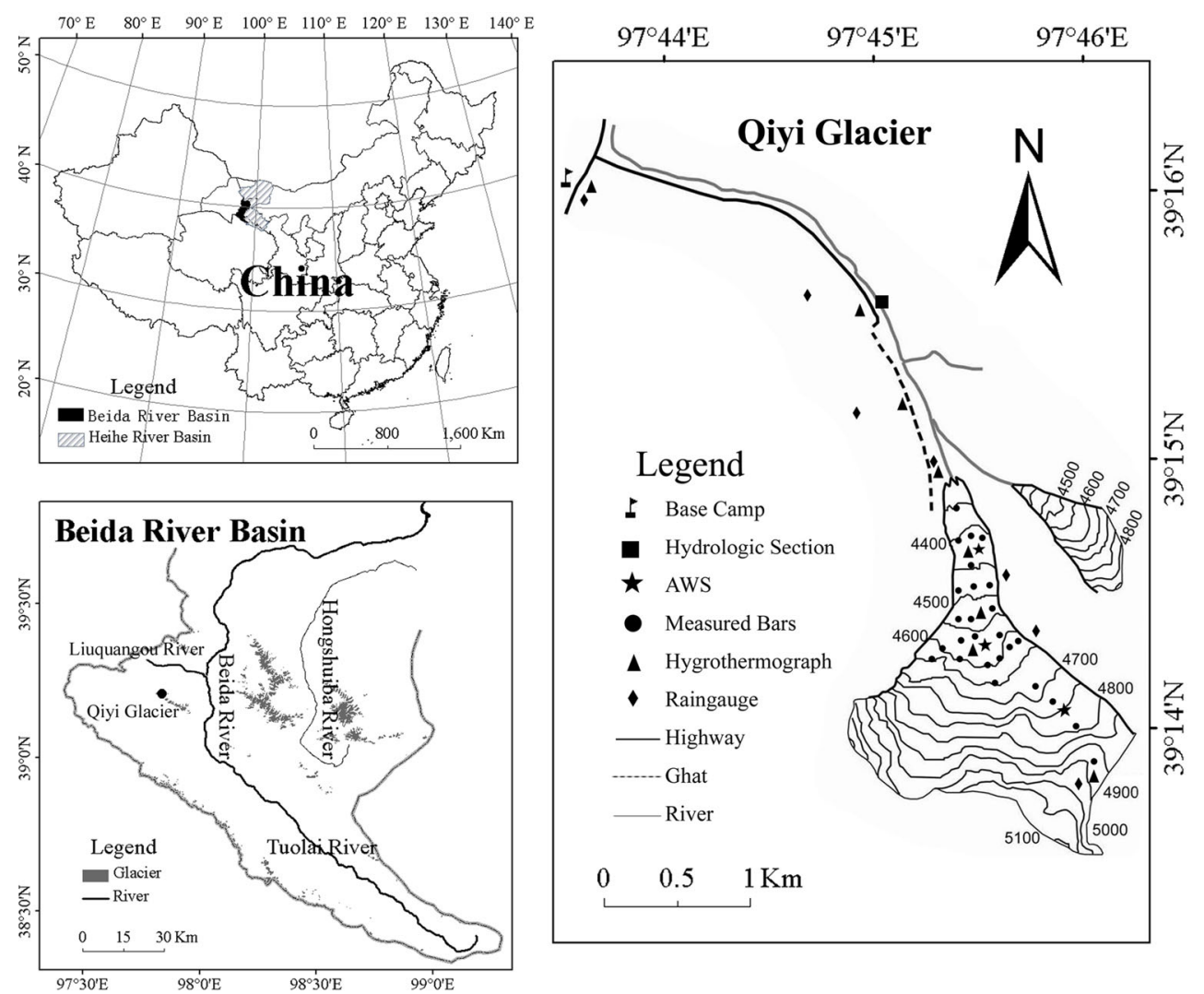

difference in climate between the mountains and plains, daily meteorological data (air temperature, precipitation, pressure, humidity and sunshine duration) from 1957 to 2012 of two mountainous meteorological stations (Tuole and Yeniugou) around the basin were chosen as the sources of the input data of the model. Meteorological data for calibrating the parameters were from the in-situ observed data of Qiyi Glacier, which included gradient observed data of air temperature and precipitation, and data (wind speed and direction, air temperature, humidity, pressure, precipitation, and 4-component radiation) from automatic weather stations (AWS). The data for validating the output results of model were from mass balance observations and early studies. The glacier boundaries were vectorized by topographic maps and Landsat TM images. In the last 50 years, glacier boundaries in the Beida River Basin had changed a lot. To promote simulation accuracy, the glacier boundaries between 1957 and 1985 were from topographic maps (a total of 15 pieces and a scale of 1:100,000) from the 1970s, while the glacier boundaries between 1986 and 2012 were from a Landsat TM image (P133 r33, 2000-5-20) that was taken under cloud-free conditions. The detailed digital elevation model (DEM) of the basin was from the Shuttle Radar Topography Mission (SRTM), with a resolution of $90 \mathrm{~m}$. DEM was used to obtain the geographical coordinate information, altitude, slope, and aspect.

\section{Model description}

The distributed degree-day mass balance model in the Beida River Basin can be described by a formula:

$B=\int_{t}\left[P_{s}-(1-f) \cdot m\right] d_{t}$

where $B\left(\mathrm{~mm}\right.$ w. e.) is the glacier mass balance; $P_{s}(\mathrm{~mm} \mathrm{w}$. e.) is the solid precipitation; $f$ is the fraction of meltwater that refreezes and does not contribute to mass loss, equal to 0.1 (Liu et al. 1996); $m$ ( $\mathrm{mm}$ w. e.) is the ablation water equivalent of ice and snow; and $t$ is the selected period.

An improved degree-day model (Pellicciotti et al. 2005) was used to simulate ice and snow melt.

$m= \begin{cases}T F \cdot T+\mathrm{SRT} \cdot(1-\alpha) \cdot I \cdot \frac{G_{s}}{I_{s}} & T>0 \\ 0 & T \leq 0\end{cases}$

where $\quad$ TF $\quad\left(3.768 \mathrm{~mm}^{\circ} \mathrm{C}^{-1} \mathrm{~d}^{-1}\right)$ and SRT $(0.00858$ $\mathrm{m}^{2} \mathrm{~mm} \mathrm{~W}^{-1} \mathrm{~d}^{-1}$ ) are two experience parameters; $T\left({ }^{\circ} \mathrm{C}\right)$ is the daily average air temperature in the study period; $\alpha$ is the albedo; $I\left(\mathrm{~W} / \mathrm{m}^{2}\right)$ is the direct solar radiation on the surface of the ice or snow on sunny days; $G_{s}\left(\mathrm{~W} / \mathrm{m}^{2}\right)$ is the observed global radiation; and $I_{s}\left(\mathrm{~W} / \mathrm{m}^{2}\right)$ is the direct solar radiation at the same observation point with $G_{s}$ on sunny days. The value of $G_{s} / I_{s}$, which is generally between 0.2 and 1.2 , greatly depends on the weather. It is large on 
sunny days and small on cloudy days. According to the multiple linear regression analysis between the radiation and meteorological data of AWS, $G_{s} / I_{s}$ is described as:

$\frac{G_{s}}{I_{s}}=-0.006 \mathrm{RH}+0.077 \mathrm{HS}+0.211$

where $\mathrm{RH}(\%)$ is the relative air humidity at a height of $1.5 \mathrm{~m}$ and HS (hours) is the sunshine duration.

The direct solar radiation can be calculated directly (Hock 1999):

$I=I_{0} \cdot\left(\frac{R_{m}}{R}\right)^{2} \cdot \varphi_{a}^{\left(\frac{P}{P_{0} \cos Z}\right)} \cdot \cos \theta$

where $I_{O}\left(1368 \mathrm{~W} / \mathrm{m}^{2}\right)$ is the solar constant; $\left(R_{m} / R\right)$ is the correction factor of the earth's orbit eccentricity, where $R$ is the instantaneous earth-sun distance and $R_{m}$ is the average earth-sun distance; $\varphi_{a}$ is the average atmospheric transparency, with a value generally between 0.6 and 0.7 ; $P_{O}(1013.25 \mathrm{hPa})$ is the standard atmospheric pressure; $P$ is the atmospheric pressure of different altitudes in glacier zone; $Z$ is the zenith angle; and $\theta$ is the solar incident angle.

The solid precipitation is calculated by the threshold temperature method (Kang et al. 1999).

$P_{s}= \begin{cases}P_{\text {total }} & T<T_{s} \\ \frac{T_{l}-T}{T_{l}-T_{s}} \cdot P_{\text {total }} & T_{s} \leq T \leq T_{l} \\ 0 & T>T_{l}\end{cases}$

$P_{l}=P_{\text {total }}-P_{s}$

where $P_{s}, P_{l}$ and $P_{\text {total }}(\mathrm{mm} \mathrm{w.} \mathrm{e.)} \mathrm{are,} \mathrm{respectively,} \mathrm{the}$ solid precipitation, liquid precipitation and total precipitation, and $T_{s}$ and $T_{l}$ are, respectively, the solid precipitation threshold temperature $\left(-0.5^{\circ} \mathrm{C}\right)$ and liquid precipitation threshold temperature $\left(2{ }^{\circ} \mathrm{C}\right)$.

The meltwater run-off depth of the glaciers $R_{I}(\mathrm{~mm})$ is described as (Young 1977; Yang 1981):

$R_{I}=\int_{t}\left[(1-f) \cdot m+P_{l}-P_{a s}\right] d_{t}$

where $P_{a s}(\mathrm{~mm})$ is the precipitation of the ablation area on the glaciers during the summer.

\section{Parameter calibration}

\section{Vertical lapse rate of air temperature and precipitation gradient}

Using the monthly altitude gradient observed data of temperature and precipitation on Qiyi Glacier from 2010 to 2012, a correlation analysis was performed with the data from Tuole and Yeniugou meteorological stations (detailed results showed in Table 1). The results showed that the
Table 1 Correlation coefficients of monthly mean air temperature and precipitation between Qiyi Glacier and meteorological stations

\begin{tabular}{lllll}
\hline & Code & Altitude $(\mathrm{m})$ & \multicolumn{2}{c}{ Correlation coefficients } \\
\cline { 3 - 5 } Air temperature & H1 & 3727 & 0.994 & 0.982 \\
& & & 0.994 & 0.981 \\
& H2 & 3975 & 0.994 & 0.981 \\
& H3 & 4101 & 0.993 & 0.979 \\
& H4 & 4304 & 0.990 & 0.976 \\
& H5 & 4392 & 0.988 & 0.974 \\
& H6 & 4470 & 0.988 & 0.974 \\
& H7 & 4608 & 0.985 & 0.969 \\
& H8 & 4884 & 0.910 & 0.748 \\
& R1 & 3717 & 0.920 & 0.792 \\
& R2 & 3960 & 0.926 & 0.804 \\
& R3 & 4120 & 0.928 & 0.805 \\
& R4 & 4250 & 0.899 & 0.806 \\
& R5 & 4516 & 0.916 & 0.808 \\
& R6 & 4670 & 0.916 & 0.808 \\
\hline
\end{tabular}

correlation coefficients of the air temperature were higher than those of precipitation at the two meteorological stations, and the correlation coefficients of both the air temperature and precipitation were stronger at Tuole than at Yeniugou. Therefore, the meteorological data at Tuole meteorological station was chosen as the model driven. According to the research of Wang et al. (2009), the vertical lapse rate of the air temperature was $0.73{ }^{\circ} \mathrm{C}$ $(100 \mathrm{~m})^{-1}$ on Qiyi Glacier in 2007/08, and the maximum precipitation altitude belt was located between 4500 and $4700 \mathrm{~m}$, where the annual precipitation was $485 \mathrm{~mm}$. According to the observations of $2010 / 11$, the vertical lapse rate of the air temperature was $0.70{ }^{\circ} \mathrm{C}(100 \mathrm{~m})^{-1}$, and the maximum precipitation site was located at $4670 \mathrm{~m}$, where the annual precipitation was $410.5 \mathrm{~mm}$. These two results were consistent. To improve the simulation precision, different vertical lapse rates of air temperature and precipitation gradients were used for different months and heightbelts. Meanwhile, the influence of the 'temperature jump' was considered when calculating the vertical lapse rates. The relative results were shown in Tables 2, 3 and 4 .

\section{Albedo}

Albedo is one of the key indicators of model simulation accuracy. The temporal resolution of the albedo simulation was 1 day in many early studies (Arnold et al. 1996; Brock et al. 2000; Oerlemans 1992; Oerlemans and Hoogendoorn 1989; Oerlemans and Kanp 1998; Kang and Ohmura 1994), especially the parameterization scheme proposed by Oerlemans and Kanp (1998) had been widely applied. 
Table 2 Values of 'temperature jump' in different months of Qiyi Glacier $\left({ }^{\circ} \mathrm{C}\right)$

\begin{tabular}{|c|c|c|c|c|c|c|c|c|c|c|c|c|}
\hline Month & Jan. & Feb. & Mar. & Apr. & May & Jun. & Jul. & Aug. & Sep. & Oct. & Nov. & Dec. \\
\hline Temperature jump $\left({ }^{\circ} \mathrm{C}\right)$ & 0.37 & 0.37 & 0.48 & 0.79 & 0.82 & 0.14 & 1.21 & 0.53 & 0.07 & 0.68 & 0.47 & 0.51 \\
\hline
\end{tabular}

Table 3 Vertical lapse rates of temperature in different months and height belts after considering the 'temperature jump' $/{ }^{\circ} \mathrm{C}(100 \mathrm{~m}){ }^{-1}$

\begin{tabular}{|c|c|c|c|c|c|c|c|c|c|c|c|c|}
\hline \multirow[t]{2}{*}{ Altitude (m) } & \multicolumn{12}{|l|}{ Month } \\
\hline & Jan. & Feb. & Mar. & Apr. & May & Jun. & Jul. & Aug. & Sep. & Oct. & Nov. & Dec. \\
\hline$<3975$ & -0.42 & -0.53 & -0.60 & -0.66 & -0.75 & -0.68 & -0.69 & -0.61 & -0.74 & -0.54 & -0.58 & -0.39 \\
\hline $3975-4101$ & -0.57 & -0.49 & -0.50 & -0.65 & -0.69 & -0.60 & -0.35 & -0.46 & -0.47 & -0.47 & -0.50 & -0.57 \\
\hline $4101-4304$ & -0.61 & -0.51 & -0.53 & -0.69 & -0.73 & -0.63 & -0.86 & -0.67 & -0.71 & -0.49 & -0.53 & -0.60 \\
\hline $4304-4392$ & -0.40 & -0.52 & -0.59 & -0.65 & -0.74 & -0.67 & -0.51 & -0.53 & -0.66 & -0.53 & -0.57 & -0.37 \\
\hline $4392-4470$ & -0.52 & -0.69 & -0.51 & -0.86 & -0.83 & -0.56 & -0.95 & -0.87 & -0.64 & -0.53 & -0.43 & -0.34 \\
\hline $4470-4608$ & -0.49 & -0.45 & -0.45 & -0.49 & -0.64 & -0.49 & -0.49 & -0.58 & -0.67 & -0.41 & -0.47 & -0.43 \\
\hline$>4608$ & -0.67 & -0.63 & -0.45 & -0.69 & -0.62 & -0.45 & -0.58 & -0.64 & -0.38 & -0.47 & -0.48 & -0.50 \\
\hline
\end{tabular}

Table 4 Precipitation gradients in different months and height-belts $\left(\mathrm{mm}[100 \mathrm{~m}]^{-1} \mathrm{~d}^{-1}\right)$

\begin{tabular}{|c|c|c|c|c|c|c|c|c|c|c|c|c|}
\hline \multirow[t]{2}{*}{ Altitude (m) } & \multicolumn{12}{|l|}{ Month } \\
\hline & Jan. & Feb. & Mar. & Apr. & May & Jun. & Jul. & Aug. & Sep. & Oct. & Nov. & Dec. \\
\hline$<3960$ & 0.41 & 0.12 & 0.21 & 0.00 & 0.82 & 0.26 & 0.38 & 0.06 & 0.15 & 0.48 & 0.18 & 0.00 \\
\hline $3960-4120$ & 0.19 & 0.31 & 0.19 & 0.63 & 0.38 & 0.31 & 0.03 & 0.16 & 0.05 & 0.82 & 0.80 & 1.91 \\
\hline $4120-4250$ & 0.23 & 0.15 & 0.38 & 0.62 & 0.31 & 0.19 & 0.09 & 0.19 & 0.15 & 1.14 & 0.83 & 2.12 \\
\hline $4250-4516$ & 0.11 & 1.50 & 0.26 & 0.26 & 0.08 & 0.14 & 0.51 & 0.09 & 0.01 & 1.36 & 1.83 & 3.88 \\
\hline $4516-4670$ & 1.03 & 0.39 & 0.39 & 0.65 & 0.39 & 0.32 & 0.16 & 0.32 & 0.67 & 2.43 & 0.99 & 1.55 \\
\hline$>4670$ & -0.24 & -0.38 & -0.24 & -0.27 & -0.29 & -0.28 & -0.24 & -0.32 & -0.14 & -0.33 & -0.44 & -0.29 \\
\hline
\end{tabular}

Kang and Ohmura (1994) proposed different parameterization formulas for ice surfaces and snow surfaces according to the features of glaciers in Western China. In the current study, the albedo of the glacier surface was calculated by a combination of the above two methods.

The albedo of the snow-covered glacier on day $\alpha_{\text {snow }}^{(i)}$ depends on the age of the snow at the surface.

$\alpha_{\text {snow }}^{(i)}=\alpha_{\text {firn }}+\left(\alpha_{\text {frsnow }}-\alpha_{\text {firn }}\right) \cdot \exp \left(\frac{s-i}{t^{*}}\right)$

where $\alpha_{\text {firn }}$ and $\alpha_{\text {frsnow }}$ are the characteristic albedo for firn and fresh snow, respectively; $t^{*}$ is a time-scale determining how fast the snow albedo transforms into firn after a snowfall; and $s$ is the day number on which the last snow occurred.

The final albedo $\alpha^{(i)}$ is described as:

$\alpha^{(i)}=\alpha_{\text {ice }}+\alpha_{\text {snow }}^{(i)} \cdot\left(a_{1}+a_{2} \cdot T+a_{3} \cdot T^{2}+a_{4} \cdot T^{3}+a_{5} \cdot T^{4}\right)$

where $\alpha_{\text {ice }}$ is the characteristic albedo for ice and $T\left({ }^{\circ} \mathrm{C}\right)$ is the air temperature at the same site of $\alpha^{(i)}$. All of the coefficients and parameters were fitted from the albedo measurements at the AWS from 2010 to 2011 $\left(\alpha_{\text {firn }}=0.537, \alpha_{\text {frsnow }}=0.769, \alpha_{\text {ice }}=0.382, t^{*}=3.008\right.$; $a_{1}=0.423, a_{2}=-5.23 \times 10^{-2}, a_{3}=-5.662 \times 10^{-3}$, $a_{4}=-2.856 \times 10^{-4}, a_{5}=4.93 \times 10^{-6}$ ).

\section{Model validation}

In West China, it is difficult to carry out the in-situ observation of glaciers, especially on the basin scale. Qiyi Glacier was the only typical glacier that had more than 10 years observation in the Beida River Basin. As a result, the in-situ observed data from Qiyi Glacier was used for model validation.

\section{Mass balance}

Using the model, the annual and monthly (in 2010/11 and 2011/12) mass balances of Qiyi Glacier were simulated and then compared to observed values (Figs. 2, 3) (Wang et al. 1984; Liu et al. 1992; Pu et al. 2005; Wang et al. 2011). The simulated values of the annual mass balance were close to the observed values, so the model performed well, 


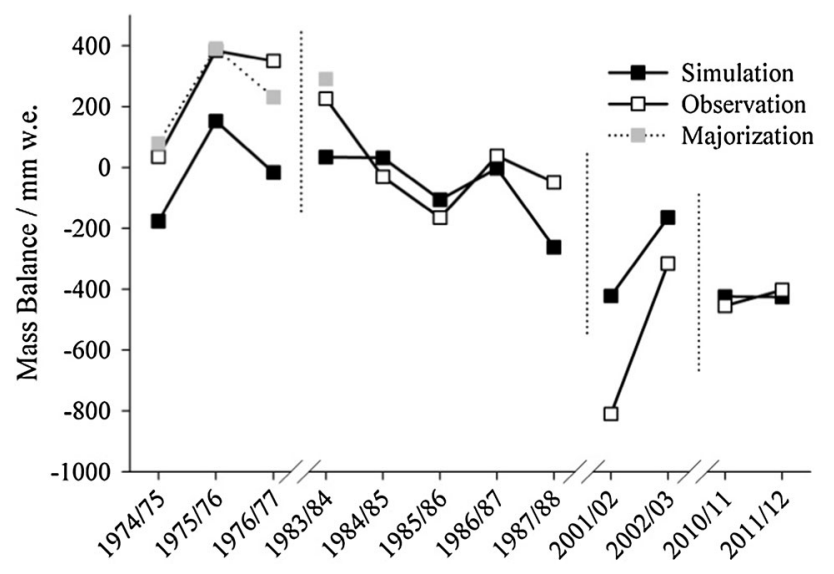

Fig. 2 Observed and simulated annual mass balances of Qiyi Glacier

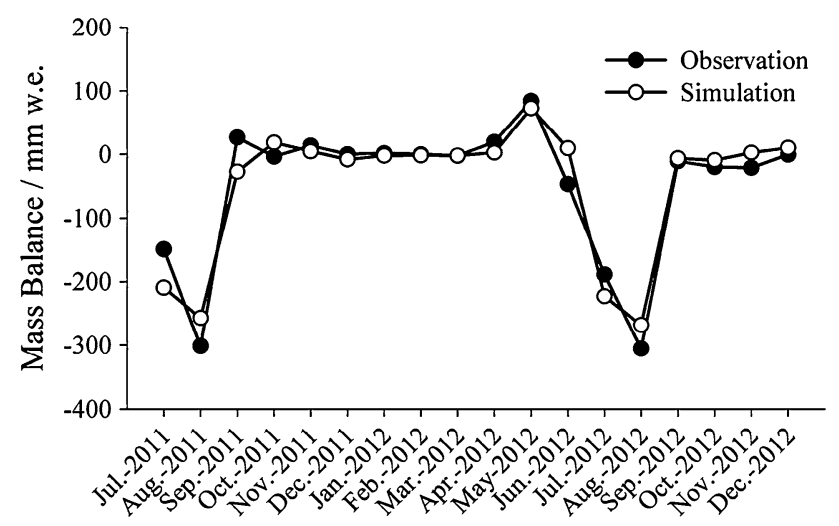

Fig. 3 Observed and simulated monthly mass balances of Qiyi Glacier from July 2011 to December 2012

especially in 2010/11 and 2011/12. The simulated value significantly exceeded the observed value only in 2001/02, which was the most negative balance year of all observed years, so the simulation may be not very precise when the climate is abnormal. As all of the parameters were calibrated using recent data, the simulated values were apparently lower than the observed values before 1983/84, but the trend of variation was consistent. This difference might have a great influence on the run-off modeling result for the former period. To reduce errors, two experience parameters (TF and SRT) were optimized using the observed values in 1974/75, 1975/76, 1976/77 and 1983/84 $\left(\mathrm{TF}=3.538 \mathrm{~mm}^{\circ} \mathrm{C}^{-1} \mathrm{~d}^{-1}\right.$ and $\mathrm{SRT}=-0.0148 \mathrm{~m}^{2} \mathrm{~mm}$ $\mathrm{W}^{-1} \mathrm{~d}^{-1}$ after majorization). The simulation accuracy was greatly improved through optimizing, and the absolute error of average mass balance among above 4 years promoted from $250.4 \mathrm{~mm}$ w. e. to $0.9 \mathrm{~mm}$ w. e.. In the monthly mass balance simulation, the results of the cold season (Oct.Apr.) were very consistent between the simulation and observation. In the warm season (May-Sep.), the model

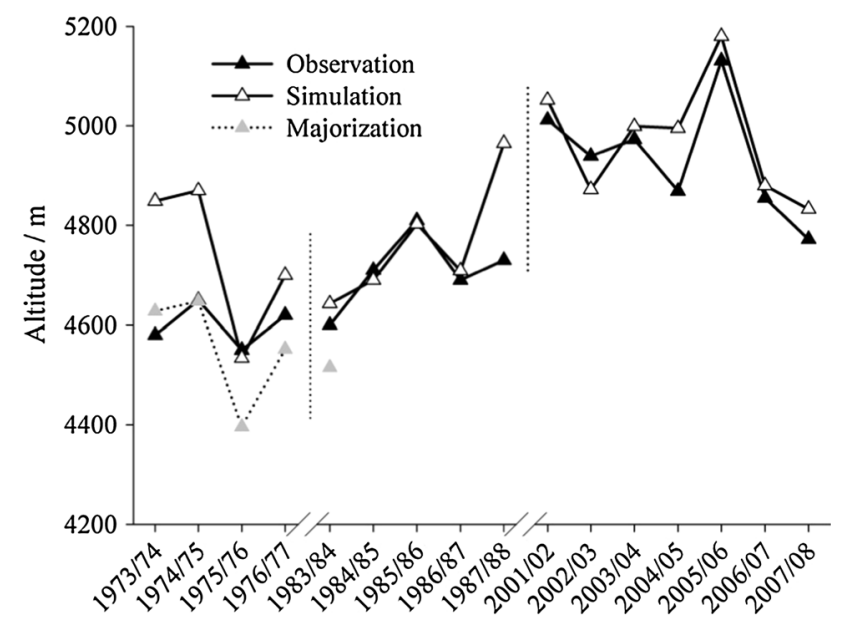

Fig. 4 Observed and simulated annual ELAs of Qiyi Glacier

also performed well in May and September, but there was a slight deviation from June to August.

\section{ELA}

Figure 4 showed the comparison between the simulated and observed annual ELAs (Wang et al. 1984; Liu et al. 1992; Wang et al. 2010) of Qiyi Glacier. The model performed remarkably well, and the results indicated good agreement between observation and simulation, especially after 2000. The modeling error still appeared before $1983 / 84$, but through optimization, the absolute error of the average ELA before 1983/84 was reduced from $119.2 \mathrm{~m}$ to $52.3 \mathrm{~m}$, a dramatic improvement in the simulation accuracy.

\section{Results}

\section{Mass balance}

The model reconstructed a glacier mass balance series in the Beida River Basin from 1957 to 2012 (Fig. 5). The annual mean mass balance of this basin was $-93.3 \mathrm{~mm} \mathrm{w}$. e., and the accumulative mass balance was $-5.1 \mathrm{~m} \mathrm{w}$. e.. The time series of the mass balance had a downward trend over 55 years. Especially after 1992/93, the mass balance was consecutively negative, and its minimum was $-679.6 \mathrm{~mm}$ w. e. which appeared in 2009/10. Table 5 shows the simulated decadal mass balance of the Beida River Basin and the observed values of Ürümqi Glacier No. 1 (Zhang 1981; Zhang et al. 1984; Jiao et al. 2000, 2004). The decadal mass balance of the glaciers in the Beida River Basin decreased continuously. Unlike for Ürümqi Glacier No. 1, the glacier mass balance in the Beida River Basin 
Fig. 5 Mass balance and accumulated mass balance of glaciers in the Beida River Basin during 1957-2012

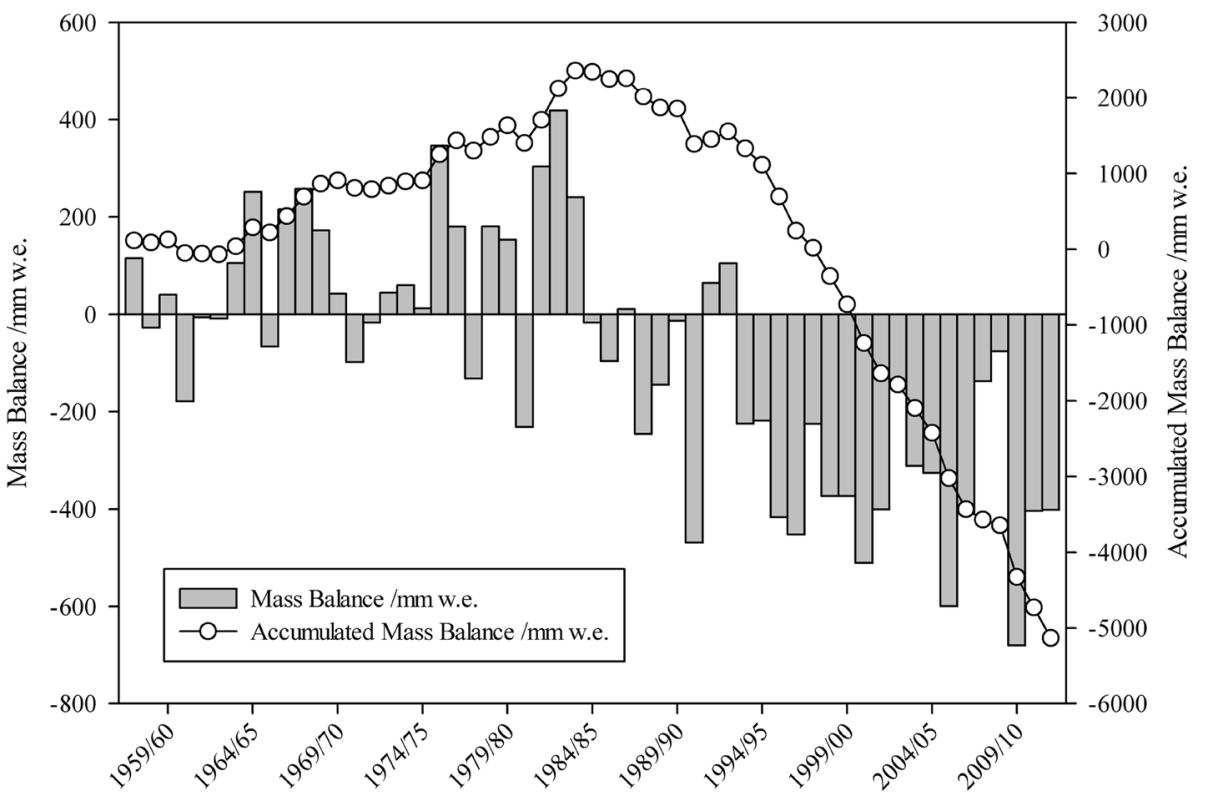

\begin{tabular}{lccccc}
\hline & $1960 \mathrm{~s}$ & $1970 \mathrm{~s}$ & $1980 \mathrm{~s}$ & $1990 \mathrm{~s}$ & After 2000 \\
\hline Beida River Basin & 77.9 & 61.6 & 38.8 & -222.4 & -367.4 \\
Ürümqi Glacier No. 1 & -75.5 & -50 & -267.5 & -403.9 & \\
\hline
\end{tabular}

Table 5 Decadal mass balance (mm w. e.) of glaciers in the Beida River Basin and Ürümqi Glacier No. 1 was positive in the 1960s, 1970s and 1980s, so the storage of the glacier increased before 1990. However, the glacier mass balance in both Ürümqi Glacier No. 1 and the Beida River Basin was negative since the 1990s. The decrements of the mass balance in the Beida River Basin were 200 and $2030 \mathrm{~mm}$ w. e./10 years before and after 1990, respectively. Therefore, the glaciers in Northwest China presented different responses to climate transformation under the effect of different glacier scales, terrains, and regional climates. With continued climate warming, the glacier mass significantly decreased, and the glaciers were all in a state of negative balance. Similar simulated results were obtained in the Tailan River Basin (Shen et al. 2003) and the Tarim River Basin (Gao et al. 2010).

Due to the complicated atmospheric circulation system, the seasonal variation of the mass balance for mountain glaciers in West China had different characteristics from maritime glaciers in Europe. In West China, both ablation and accumulation mainly happened in warm season. Additional ice developed extensively, and the supply in the glacier interior was large (Xie 1980). Variations of the monthly mass balance in the Beida River Basin were illustrated in Fig. 6. The mass balance was near-zero in the cold season (Oct.-Apr.), with an average of $11.3 \mathrm{~mm} \mathrm{w}$. e. In the warm season (May-Sep.), the accumulation was mainly in May, June and September, with an accumulated mass balance of $137.2 \mathrm{~mm}$ w. e., while the ablation was mainly in July and August, with an accumulated mass balance of $-310.5 \mathrm{~mm}$ w. e.. These monthly change characteristics of the mass balance were controlled by the air temperature and precipitation. In the cold season, the average air temperature and precipitation at the Tuole meteorological station were $-9.8^{\circ} \mathrm{C}$ and $3.5 \mathrm{~mm}$, respectively, which caused weak ablation and accumulation. As the air temperature rose and precipitation increased in the warm season, the ablation and accumulation of glaciers both increased. The supply of precipitation to the glacier accumulation was obvious in May, June and September. The strongest ablation periods of the glaciers were in July and August, which were the hottest months in a year. During this period, precipitation would fall as rain, which would cause the reduction of the glacier surface albedo, promoting the ablation of glaciers (Fujita 2008). The process of the glacier mass balance during the summer showed an obvious temperature response. As a result, the summer (Jul., Aug.) temperature and warm season (May-Sep.) precipitation are key factors that cause the seasonal variations in the mass balance.

To explore the altitude profile characteristics of the mass balance and its possible influencing factors, the monthly mass balance was spatially averaged (at a $100 \mathrm{~m}$ altitude interval) and the altitude distribution was determined 
Fig. 6 Monthly glacier mass balance in the Beida River Basin and monthly mean air temperature and precipitation at the Tuole meteorological station

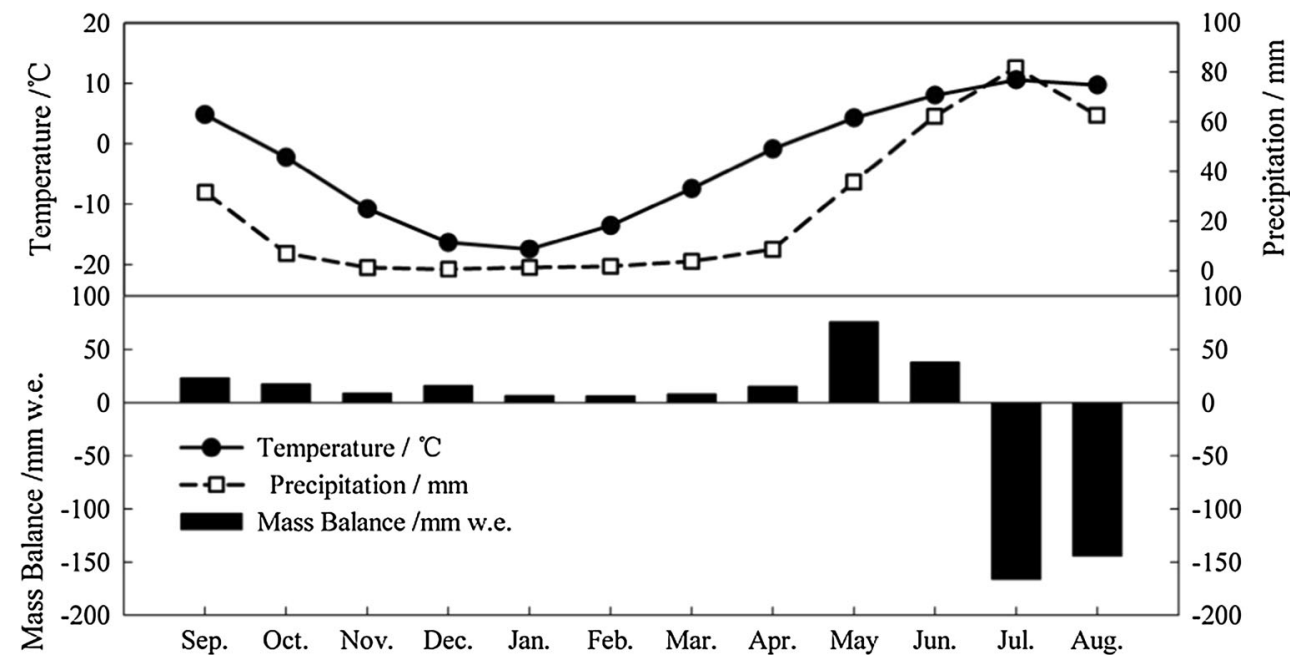

Mass Balance / $\mathrm{mm}$ w.e.
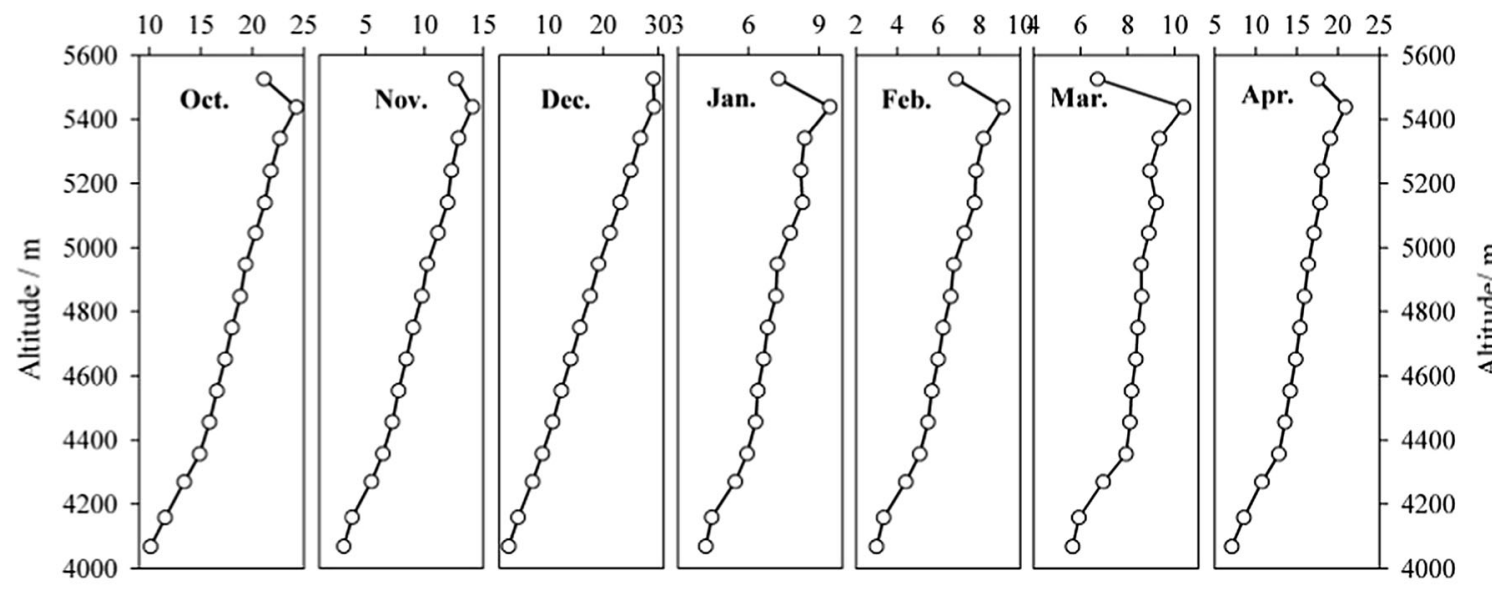

Mass Balance / $\mathrm{mm}$ w.e.
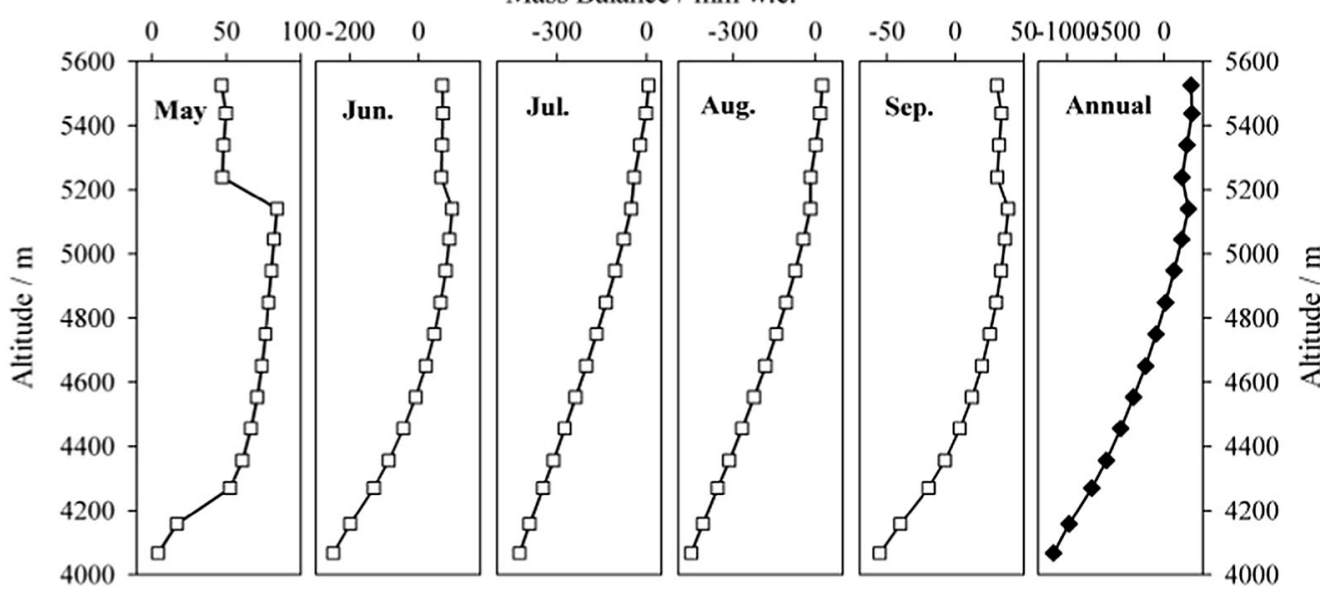

Fig. 7 Variations in the monthly and annual mass balance with altitude

(Fig. 7). In the cold season, the monthly mass balance varied irregularly below $4200 \mathrm{~m}$ and above $5400 \mathrm{~m}$. However, the mass balance linearly increased with altitude from 4200 to $5400 \mathrm{~m}$, and the coefficient of determination
$\left(R^{2}\right)$ exceeded 0.97, except in March (0.868). The linearity was excellent between the accumulated mass balance in the cold season and the altitude within 4200-5400 m, and the coefficient of determination was up to 0.995 . In the warm 
season, the monthly mass balance increased exponentially with the altitude. In May, June, and September, the exponential relationship only existed in the altitude intervals below $5200 \mathrm{~m}$, with coefficients of determination of 0.779 , 0.945 , and 0.927 , respectively, while the mass balance had almost no change above $5200 \mathrm{~m}$. In July and August, the monthly mass balance increased exponentially at all altitude intervals, with coefficients of determination of 0.989 and 0.973 , respectively. Throughout the year, the annual mass balance of the glaciers in the Beida River Basin also increased exponentially with altitude, and the coefficient of determination was up to 0.928 .

\section{ELA}

The equilibrium line altitude (ELA) is the average altitude of the glacier at which the annual mass accumulation and loss are equal. Glacier advance or retreat is directly decided by the ELAs change. Compared with other characteristic parameters (e.g., length or area), the variation of the ELA is the most direct reflection of climate change (Wang et al. 2010). The interannual variability of ELAs from 1957 to 2012 in the Beida River Basin is illustrated in Fig. 8a. The ELAs first declined then rose over 55 years. The lowest ELA (4322 m) appeared in 1982/83, and the highest ELA $(5258 \mathrm{~m})$ appeared in $2005 / 06$. Assuming a continuous linear trend, the ELA increased by $505 \mathrm{~m}$ from 1957 to 2012. The mass loss of mountain glaciers in the middle or high latitudes was dominantly caused by ablation. The ELAs in these areas showed a strong sensitivity to the air temperature change of warm seasons (Ohmura et al. 1992), and the air temperature was the most important factor that caused the variation of the ELA. The interannual variability characteristics of ELAs for glaciers in the Beida River Basin were a direct response to the climatic transition in Western China.

Similar to the simulated ELAs of glaciers in the Beida River Basin during 1957-2012 (Fig. 8a), the time series of the ELA on Qiyi Glacier (Wang et al. 2010) during
1957-2008 (Fig. 8b) also showed a trend that first decreased slowly then increased significantly. Before 1985, the interannual variation in the ELA for the glaciers in the Beida River Basin was in accord with that of Qiyi Glacier. During this period, the average ELA of the glaciers in the Beida River Basin was 4676 m, compared with an average on Qiyi Glacier of $4690 \mathrm{~m}$. However, the increase in the ELA for glaciers in the Beida River Basin was significantly greater than that of Qiyi Glacier after 1985. The average ELA of glaciers in the Beida River Basin increased to $4989 \mathrm{~m}$ during 1986-2008, while it was only $4822 \mathrm{~m}$ on Qiyi Glacier. A large number of statistical data showed that an excellent linear relationship existed between the annual mass balance and ELA for the same year (Braithwaite 1984). When annual mass balance of glaciers in the Beida River Basin was zero, i.e., the glaciers were in a stable state, the balance-budget equilibrium line altitude $\left(\mathrm{ELA}_{0}\right)$ was $4752.2 \mathrm{~m}$. The ELA of glaciers in the Beida River Basin was $18 \mathrm{~m}$ lower than that on Qiyi Glacier when the annual mass balance of the glaciers in the Beida River Basin was positive, but it was $127 \mathrm{~m}$ higher when the annual mass balance was negative. Among all the investigated glaciers in the Beida River Basin, the local climate and surrounding terrain of Qiyi Glacier had good regional representations, but the area of this glacier $\left(2.76 \mathrm{~km}^{2}\right)$ is larger than $98.6 \%$ of the glaciers in the study area. Consequently, when subjected to climate warming, the ELAs of the smaller glaciers increased faster because small glaciers in mountainous regions exhibited a stronger response to climate change and a shorter response time (Oerlemans and Fortuin 1992). The effect of the glacier scale on the ELA would gradually strengthen as climate warming continued.

\section{Meltwater run-off}

In the arid and semi-arid regions of Western China, mountain glaciers are an important component of surface water resources. Glaciers meltwater run-off provides
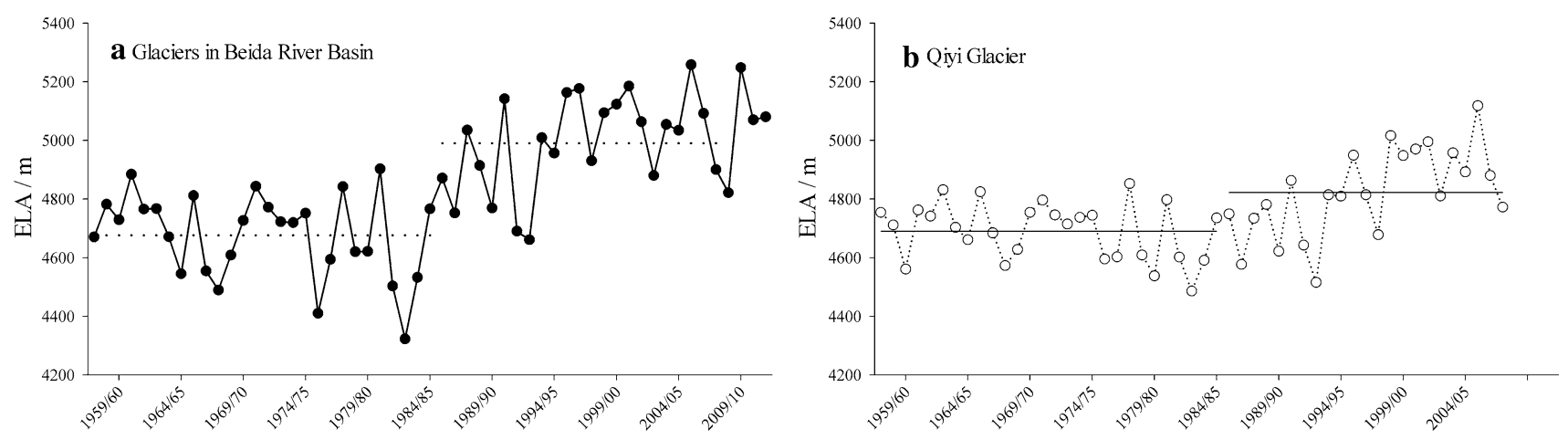

Fig. 8 Simulated ELAs of glaciers in the Beida River Basin during 1957-2012 and Qiyi Glacier during 1957-2008 (Wang et al. 2010) 
Fig. 9 Simulated meltwater run-off depth and accumulated meltwater run-off depth in the Beida River Basin during 1958-2012

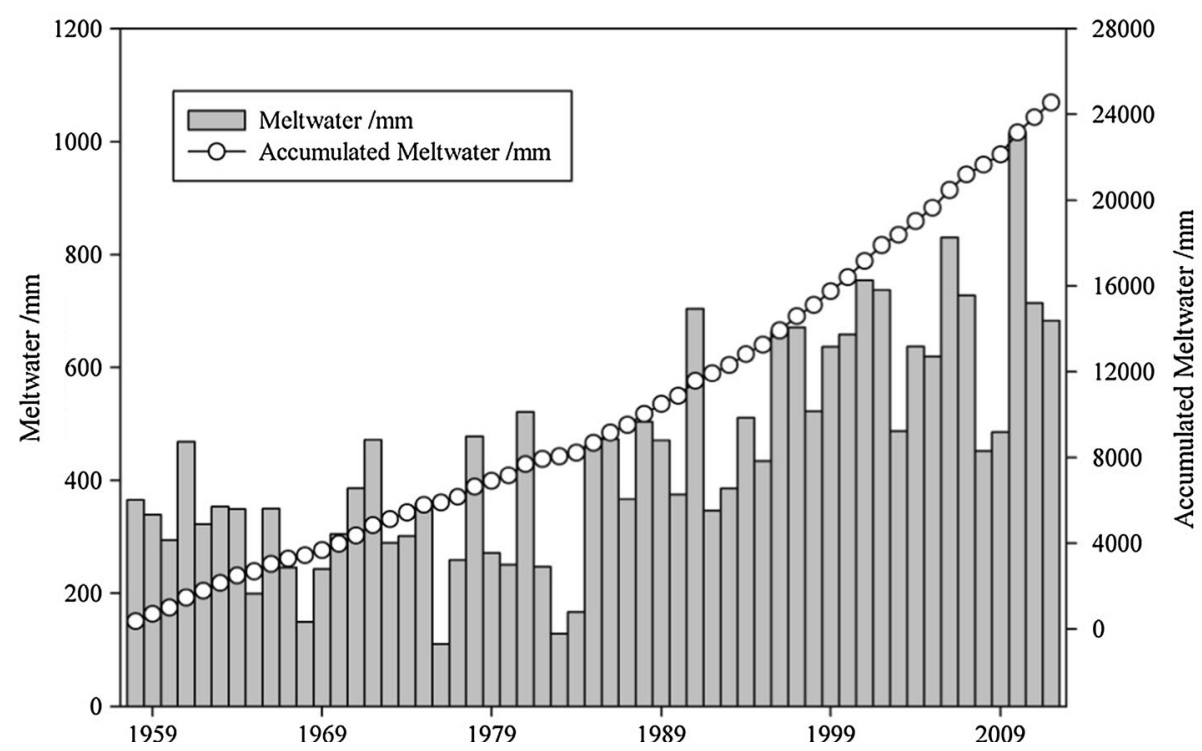

precious freshwater and supplies river run-off (Jansson et al. 2003). The simulated annual and accumulated meltwater run-off depths $(\mathrm{mm})$ in the Beida River Basin during 1958-2012 were illustrated in Fig. 9. The annual average meltwater run-off depth of the Beida River Basin was $443 \mathrm{~mm}$, and the accumulated meltwater run-off was approximately $65.12 \times 10^{8} \mathrm{~m}^{3}$ over the 55 years. As the climate patterns transformed from warm-dry to warm-wet in 1986/87 (Shi et al. 2003), the glaciers in the Beida River Basin strongly melted, and the meltwater run-off generally increased.

\section{Discussion}

\section{Abrupt change point analysis}

To investigate the interannual variation of the glacier mass balance, ELA and meltwater run-off in the Beida River Basin, the trend and abrupt change point analysis of the above three time series was conducted using the Mann-Kendall (M-K) test (Hirsch and Slack 1984; Wei 2008), which was a nonparametric statistical test method. The UF curve (Fig. 10a) of the mass balance showed that it had decreased significantly since the middle of the 1990s. Especially after 2000, the significance level of the decreasing trend vastly exceeded the 0.05 critical value $\left(\alpha_{0.05}= \pm 1.96\right)$ and even the 0.01 critical value $\left(\alpha_{0.01}= \pm 2.56\right)$. Thus, the decreasing trend was quite significant. According to the intersection between the UF and UB curves, the most likely abrupt change point of the glacier mass balance time series was in 1992/93. The mass balance was positive in most years before 1992/93, and then turned increasingly negative over time. The average mass balances of the two periods (before and after the abrupt change point) were, respectively, 43.2 and $-351.9 \mathrm{~mm}$ w. e., with a decrement of $395.1 \mathrm{~mm}$ w. e. The most likely abrupt change point of the ELA (Fig. 10b) and meltwater run-off depth (Fig. 10c) time series was also in 1992/93, the same as the result of the mass balance, but both the ELA and meltwater run-off depth increased significantly since 1993. The average ELA increased by $344.4 \mathrm{~m}$ before and after 1992/93, and the increment of the meltwater run-off depth was $302.2 \mathrm{~mm}$. According to the annual air temperature and precipitation data from Tuole and Yeniugou meteorological stations, the air temperature in the Beida River Basin rose by $1.04{ }^{\circ} \mathrm{C}$ before and after 1992/93, and the increment of the precipitation was $32.4 \mathrm{~mm}$. As the key factors that caused a change in the mass balance, the air temperature in the summer and the precipitation in the warm season of the two meteorological stations, respectively, increased by $1.07{ }^{\circ} \mathrm{C}$ and $27.4 \mathrm{~mm}$ before and after 1992/93. Even if all of the increasing precipitation accumulated and then transformed into glacier storage, it only accounted for $8.2 \%$ of the mass balance decrements. In fact, $84.6 \%$ of the increasing precipitation was concentrated in the warm season; this part of precipitation would fall as rain with climate warming. The fresh snow would decrease, causing a reduction in the glacier surface albedo, which would lead to the greater ablation of glaciers (Fujita 2008). For the above reasons, the increase in precipitation clearly could not compensate for the net mass loss induced by an air temperature increase. The consecutive negative balances of the glaciers in the Beida River Basin were controlled by the continuous warming, which further caused the rapid rise in the ELA and an increase of meltwater run-off. 

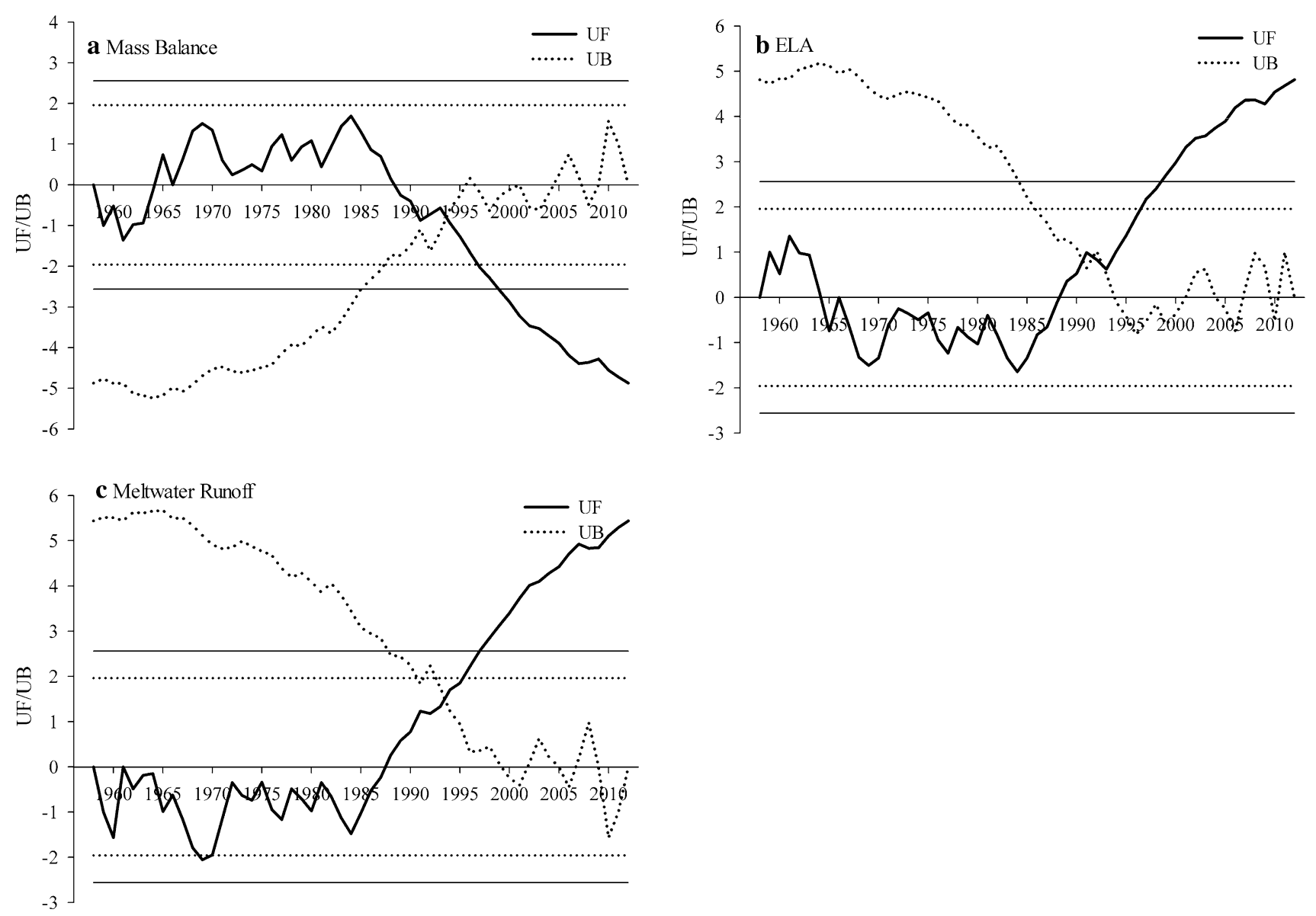

Fig. 10 Results of M-K test for a glacier mass balance, b ELA and $\mathbf{c}$ meltwater run-off (horizontal dotted lines and horizontal solid lines represent critical value of 0.05 and 0.01 significance level, respectively)

\section{Climate sensitivity test}

As a typical basin in the upper reaches of the Heihe River, the Beida River Basin is recognized as a sensitive area for climate change. A climate sensitivity test was carried out in the Beida River Basin. In the test, air temperature and precipitation, which were two important climate elements, were altered by $1{ }^{\circ} \mathrm{C}$ and $10 \%$, respectively. The impacts on the glacier mass balance, ELA, and meltwater run-off were studied, and the test results are shown in Table 6 (Test program 1 was under the mean climate conditions during 2000-2012).
The response of the ELA to climate change was different in different regions of the world. Table 7 shows some response values of the ELA upon increasing the temperature $\left(+1{ }^{\circ} \mathrm{C}\right)$ or precipitation $(+10 \%)$ on different glaciers. The increments in the ELA caused by the increasing temperature were considerably larger than the decrements caused by the increasing precipitation. Results in the Beida River Basin also accorded with the above characteristic. Thus, compared with precipitation, the response of the ELA to temperature was much more sensitive. When the air temperature and precipitation were increased by $1{ }^{\circ} \mathrm{C}$ and $10 \%$, respectively, the response

Table 6 Climate sensitivity test

\begin{tabular}{lcclcrrr}
\hline $\begin{array}{l}\text { Test } \\
\text { program }\end{array}$ & $\begin{array}{l}\text { Air temperature } \\
\text { change }\left({ }^{\circ} \mathrm{C}\right)\end{array}$ & $\begin{array}{l}\text { Precipitation } \\
\text { change }(\%)\end{array}$ & $\begin{array}{l}\text { ELA } \\
(\mathrm{m})\end{array}$ & $\begin{array}{l}\text { Mass balance } \\
(\mathrm{mm})\end{array}$ & $\begin{array}{l}\text { Relative } \\
\text { rate }(\%)\end{array}$ & $\begin{array}{l}\text { Meltwater } \\
\text { run-off }(\mathrm{mm})\end{array}$ \\
\hline 1 & 0 & 0 & 5036.8 & -361.9 & 0.0 & 664.6 & $\begin{array}{l}\text { Relative } \\
\text { rate }(\%)\end{array}$ \\
2 & +1 & 0 & 5201.8 & -675.0 & -86.5 & 972.3 & 0.0 \\
3 & 0 & +10 & 5021.5 & -344.7 & 4.7 & 666.7 & 46.3 \\
4 & +1 & +10 & 5189.1 & -660.9 & -82.6 & 975.4 & 46.7 \\
\hline
\end{tabular}


Table 7 Response values of ELA by increasing the temperature $\left(+1{ }^{\circ} \mathrm{C}\right)$ or precipitation $(+10 \%)$ on different glaciers

\begin{tabular}{llll}
\hline Glaciers & Temperature increased $1{ }^{\circ} \mathrm{C}(\mathrm{m})$ & Precipitation increased 10\% $(\mathrm{m})$ & References \\
\hline Severnaya Zemlya & $175-241$ & -50 to -70 & Bassford et al. (2006) \\
Solheimajokull & 160 & -22 & Mackintosh et al. (2002) \\
East Ürümqi Glacier No. 1 & 238 & -29 & Wang and Zhou (1996) \\
West Ürümqi Glacier No. 1 & 122 & -10 & Wang and Zhou (1996) \\
Qiyi Glacier & 172 & -62 & Wang et al. (2010) \\
Beida River basin & 165 & -15 & This paper \\
\hline
\end{tabular}

values of the mass balance were -313.2 and $17.2 \mathrm{~mm} \mathrm{w}$. e., compared to -214 and $354 \mathrm{~mm}$ w. e. on the Hailuogou Glacier (Xie et al. 2001), a maritime glacier. There were different response mechanisms to climate change for maritime glaciers and continental glaciers. The air temperature was a dominant influencing factor for the mass balance of continental glaciers, while the mass balance of maritime glaciers was extremely sensitive to both air temperature and precipitation, and precipitation may be the more sensitive climate element. If the air temperature $\left(+1{ }^{\circ} \mathrm{C}\right)$ and precipitation $(+10 \%)$ increased simultaneously, the mass loss and meltwater run-off increased to $1.66 \times 10^{8} \mathrm{~m}^{3}$ and $2.45 \times 10^{8} \mathrm{~m}^{3}$. Compared with the values in the early twenty-first century, the mass loss and meltwater run-off increased by $0.75 \times 10^{8} \mathrm{~m}^{3}$ and $0.78 \times 10^{8} \mathrm{~m}^{3}$, respectively.

\section{Concluding remarks}

Based on in-situ observations on Qiyi Glacier from 2010 to 2012, driven by daily meteorological data from the Tuole meteorological station and combined with DEM, digital topographic maps and Landsat TM images, a daily distributed degree-day model on a $90 \times 90 \mathrm{~m}$ grid was developed for the Beida River Basin. Utilizing this model, the time series of the glacier mass balance, ELA and meltwater run-off were reconstructed for 1957-2012. In general, the model performed remarkably well, and the simulations were consistent with observations. Through trend analysis, abrupt change point analysis and climate sensitivity test, the mass loss of the glaciers in the Beida River Basin tended to accelerate with the recent climate warming, and this accelerating trend was more obvious for small glaciers. In the short term, the accelerating mass loss would lead to an increase of meltwater run-off, which would greatly influence the water cycle and water resource utilization. Variations of the underlying surface caused by the shrinkage of glaciers also had an effect on regional climate change. Thus, it was significant to predict future glacier and run-off changes in mountain regions.
Glaciers in West China are located in remote mountainous regions, so that it is difficult to widely carry out insitu observations, especially on the basin scale. The lack of measured data makes it difficult to calibrate modeling parameters and verify simulation results. To solve this problem, systematic and comprehensive observations on a typical glacier are needed, and then the obtained fieldbased measured data could be used in simulated studies on the basin scale, so that an accurate assessment of glacier and meltwater run-off changes for a basin could be made.

Acknowledgments This research was funded by the National Natural Science Foundation of China (No. 41171056). We thank Prof. Yao Tandong for helpful reviews of the original manuscript and Dr. Zhang Huawei for providing topographical maps of the Beida River Basin.

\section{References}

Arnold NS, Willis IC, Sharp MJ et al (1996) A distributed surface energy-balance model for a small valley glacier. I. Development and testing for Haut Glacier d'Arolla, Valais, Switzerland. J Glaciol 42:77-89

Barnett TP, Adam JC, Lettenmaier DP (2005) Potential impacts of a warming climate on water availability in snow-dominated regions. Nature 438:303-309. doi:10.1038/nature04141

Bassford RP, Siegert MJ, Dowdeswell JA (2006) Quantifying the mass balance of ice caps on Severnaya Zemlya, Russian High Arctic III: sensitivity of ice caps in Severnaya Zemlya to future climate change. Arct Antarct Alp Res 38:21-33. doi:10.1657/ 1523-0430(2006)038[0021:QTMBOI]2.0.CO;2

Braithwaite RJ (1984) Can the mass balance of a glacier be estimated from its equilibrium line altitude? J Glaciol 30:364-368

Braithwaite RJ, Olesen OB (1993) Seasonal variation of ice ablation at the margin of the Greenland ice sheet and its sensitivity to climate change, Qamanârssûp, West Greenland. J Glaciol 39:267-274

Braithwaite RJ, Zhang Y (2000) Sensitivity of mass balance of five Swiss glaciers to temperature changes assessed by tuning a degree-day model. J Glaciol 46:7-14. doi:10.3189/ 172756500781833511

Brock BW, Willis IC, Sharp MJ et al (2000) Modelling seasonal and spatial variations in the surface energy balance of Haut Glacier d'Arolla, Switzerland. Ann Glaciol 31:53-62. doi:10.3189/ 172756400781820183

Cazenave A, Dominh K, Guinehut S et al (2009) Sea level budget over 2003-2008: a reevaluation from GRACE space gravimetry, 
satellite altimetry and Argo. Global Planet Change 65:83-88. doi:10.1016/j.gloplacha.2008.10.004

Chen H, Li ZQ, Wang PY et al (2013) Change of glaciers in the general Qilian mountains. Arid Zone Res 30:588-593

Cuffey KM, Paterson WSB (2010) The physics of glaciers, 4th edn. Academic Press, New York, pp 91-136

Fujita K (2008) Effect of precipitation seasonality on climatic sensitivity of glacier mass balance. Earth Planet Sci Lett 276:14-19. doi:10.1016/j.eps1.2008.08.028

Gao X, Ye BS, Zhang SQ et al (2010) Glacier runoff variation and its influence on river runoff during 1961-2006 in the Tarim River Basin, China. Sci China (Ser D) 53:880-891. doi:10.1007/ s11430-010-0073-4

Gardner AS, Moholdt G, Cogley JG et al (2013) A reconciled estimate of glacier contributions to sea level rise: 2003 to 2009. Science 340:852-857. doi:10.1126/science. 1234532

Hirsch RM, Slack JR (1984) A nonparametric trend test for seasonal data with serial dependence. Water Resour Res 20:727-732. doi:10.1029/WR020i006p00727

Hock R (1999) A distributed temperature-index ice- and snowmelt model including potential direct solar radiation. J Glaciol 45:101-111

Hock R (2003) Temperature index melt modeling in mountain areas. J Hydrol 282:104-115. doi:10.1016/S0022-1694(03)00257-9

Huai BJ, Li ZQ, Sun MP et al (2014) RS analysis of glaciers change in the Heihe River Basin in the last 50 years. Acta Geogr Sin 69:365-377

Jansson P, Hock R, Schneider T (2003) The concept of glacier storage: a review. J Hydrol 282:116-129. doi:10.1016/S00221694(03)00258-0

Jiao KQ, Wang CZ, Han TD et al (2000) A strong negative mass balance recently appeared in the Glacier No. 1 at the headwaters of the Ürümqi River. J Glaciol Geocryol 22:62-64

Jiao KQ, Jing ZF, Han TD et al (2004) Variation of the Glacier No. 1 at the headwaters of the Ürümqi River in the Tianshan Mountains during the past 42 years and its trend prediction. J Glaciol Geocryol 26:253-260

Jóhannesson T, Sigurdsson O, Laumann T et al (1995) Degree-day glacier mass-balance modelling with applications to glaciers in Iceland, Norway and Greenland. J Glaciol 41:345-358

Kang ES, Ohmura A (1994) A parameterized energy balance model of glacier melting on the Tianshan Mountain. J Geogr Sci 49:467-476

Kang ES, Cheng GD, Lan YC et al (1999) The runoff response to climate change model in continental river basins in arid zones of Northwest China. Sci China (Ser D) 29(S1):47-54

Kaser G, Cogley JG, Dyurgerov MB et al (2006) Mass balance of glaciers and ice caps: consensus estimates for 1961-2004. Geophys Res Lett 33:L19501. doi:10.1029/2006GL027511

Lemke P, Ren J, Alley RB et al (2007) Observations: changes in snow, ice and frozen ground. Climate change 2007: the physical science basis. Cambridge University Press, Cambridge, pp 337-383

Liu CH, Xie ZC, Yang HA et al (1992) Observation, interpolation and trend study of glacier mass balance on the Qiyi Glacier in Qilian Mountain. The Monitoring of Glacier, Climate, Runoff Changes and the Research of Cold Region Hydrology in Qilian Mountains. Science Press, Beijing, pp 21-33

Liu SY, Ding YJ, Ye BS et al (1996) Study on the mass balance of the Glacier No. 1 at the headwaters of the Ürümqi river using degree-day method. In: Proceeding of the fifth Chinese conference on glaciology and geocryology, vol 1. Gansu Culture Press, Lanzhou, pp 197-204

Liu SY, Ding YJ, Wang NL et al (1998) Mass balance sensitivity to climate change of the Glacier No. 1 at the Ürümqi River head. Tianshan Mountains. J Glaciol Geocryol 20:9-13
Liu SY, Shen YP, Sun WX et al (2002) Glacier variation since the maximum of the Little Ice Age in the Western Qilian Mountains, Northwest China. J Glaciol Geocryol 24:227-233

Liu SY, Ding YJ, Zhang Y et al (2006) Impact of the glacial change on water resources in the Tarim River Basin. J Geogr Sci 61:482-490

Mackintosh AN, Dugmore AJ, Hubbard AL (2002) Holocene climatic changes in Iceland: evidence from modelling glacier length fluctuations at Sólheimajökull. Quat Int 91:39-52. doi:10.1016/ S1040-6182(01)00101-X

Meier MF (1984) Contribution of small glaciers to global sea level. Science 226:1418-1421. doi:10.1126/science.226.4681.1418

Meier MF, Dyurgerov MB, Rick UK et al (2007) Glaciers dominate eustatic sea-level rise in the $21 \mathrm{st}$ century. Science 317:1064-1067. doi:10.1126/science.1143906

Oerlemans J (1992) Climate sensitivity of glaciers in southern Norway: application of an energy-balance model to Nigardsbreen, Hellstugubreen and Alfotbreen. J Glaciol 38:223-232

Oerlemans J, Fortuin JPF (1992) Sensitivity of glaciers and small ice caps to greenhouse warming. Science 258:115-117. doi:10.1126/ science. 258.5079 .115

Oerlemans J, Hoogendoorn NC (1989) Mass balance gradients and climate change. J Glaciol 35:399-405

Oerlemans J, Kanp WH (1998) A 1 year record of global radiation and albedo in the ablation zone of Morteratschgletscher Switzerland. J Glaciol 44:231-238

Ohmura A, Kasser P, Funk M (1992) Climate at the equilibrium line of glaciers. J Glaciol 38:397-411

Pellicciotti F, Brock B, Strasser U et al (2005) An enhanced temperature-index glacier melt model including the shortwave radiation balance: development and testing for Haut Glacier d'Arolla, Switzerland. J Glaciol 51:573-587. doi:10.3189/ 172756505781829124

Pfeffer WT, Harper JT, O'Neel S (2008) Kinematic constraints on glacier to 21st-century sea-level rise. Science 321:1340-1343. doi:10.1126/science.1159099

Pu JC, Yao TD, Duan KQ et al (2005) Mass Balance of the Qiyi Glacier in the Qilian Mountains: a new observation. J Glaciol Geocryol 27:199-206

Reeh N (1991) Parameterization of melt rate and surface temperature on the Greenland ice sheet. Polarforschung 59:113-128

Shen YP, Liu SY, Zhen LL et al (2001) Fluctuations of glacier mass balance in watersheds of Qilian Mountain and their impact on water resources of Hexi Region. $J$ Glaciol Geocryol 23:244-250

Shen YP, Liu SY, Ding YJ et al (2003) Glacier mass balance change in Tailanhe River Watersheds on the south slope of the Tianshan Mountains and its impact on water resources. J Glaciol Geocryol 25:124-129

Shi YF, Zhang XS (1995) The impact of climate change on surface water resources in arid areas of Northwest China and the future trends. Sci China (Ser B) 25:968-977

Shi YF, Shen YP, Li DL et al (2003) Discussion on the present climate change from warm-dry to warm-wet in Northwest China. Quat Sci 23:152-164

Wang NL, Zhang XS (1992) Mountain glacier fluctuations and climatic change during the last 100 years. J Glaciol Geocryol $14: 242-250$

Wang NL, Zhou YB (1996) A new approach of analyzing the influence of climate change on the ELA: application of grey theory in glaciology. In: Proceeding of the fifth Chinese conference on glaciology and geocryology, vol 1. Gansu Culture Press, Lanzhou, pp 205-212

Wang ZT, Liu CH, You GX et al (1981) Glacier Inventory of China I: Qilian Mountains. Lanzhou Institute of Glaciology and Geocryology, Chinese Academy of Sciences, Gansu, pp 85-119 
Wang ZX, Xie ZC, Wu GH (1984) Glacier mass balance in Qilian Mountain. Glacier Variations and Utilizations in Qilian Mountains. Science Press, Beijing, pp 41-53

Wang GX, Li Q, Chen GD et al (2001) Climate change and its impact on the eco-environment in the source regions of the Yangtze and Yellow Rivers in recent 40 years. J Glaciol Geocryol 23:346-352

Wang NL, He JQ, Jiang X et al (2009) Study on the zone of maximum precipitation in the north slopes of the central Qilian Mountains. J Glaciol Geocryol 31:395-403

Wang NL, He JQ, Pu JC et al (2010) Variations in equilibrium line altitude of the Qiyi Glacier, Qilian Mountains, over the past 50 years. Chin Sci Bull 55:3810-3817. doi:10.1007/s11434-0104167-3

Wang S, Pu JC, Wang NL (2011) Study on mass balance and sensibility to climate change in summer on the Qiyi Glacier, Qilian Mountains. J Glaciol Geocryol 33:1214-1221

Wei FY (2008) Statistical diagnosis and predicted technology for modern climate, 2nd edn. China Meteorological Press, Beijing, pp 1-296

Xie ZC (1980) Mass balance of glacier and its relationship with characteristics of glaciers. J Glaciol Geocryol 2:1-10

Xie ZC, Su Z, Shen YP et al (2001) Mass balance and water exchange of Hailuogou Glacier in Mount Gongga and their influence on glacial melt runoff. J Glaciol Geocryol 23:7-15

Yan HD, Li ZQ, Gao WY et al (2012) RS-based monitoring of glacier change in the Beidahe River Basin in the Qilian Mountains. Arid Zone Res 29:245-250
Yang ZN (1981) The basic characteristics of runoff in the modern glaciation areas of China. Sci China 4:468-476

Yang JP, Ding YJ, Shen YP et al (2004) Climatic features of ecoenvironment change in the source regions of the Yangtze and Yellow Rivers in recent 40 years. J Glaciol Geocryol 26:7-16

Yao TD, Thompson L, Yang W et al (2012) Different glacier status with atmospheric circulations in Tibetan Plateau and surroundings. Nat Clim Change 2:663-667. doi:10.1038/nclimate1580

Young GJ (1977) The seasonal and diurnal of glacier-fed stream, Peyton Glacier, Alberta. In: Proceedings of Alberta Water-shed Research Program Symposium, Edmonton Alberta 1-16

Zhang JH (1981) Mass balance studies on the No. 1 Glacier of Ürümqi River in Tianshan. J Glaciol Geocryol 3:32-40

Zhang JH, Wang XJ, Li J et al (1984) Study on relationship between mass balance change of Glacier No. 1 at the headwater of Ürümqi River. Tianshan and climate. J Glaciol Geocryol 6:25-36

Zhang Y, Liu SY, Shangguan DH et al (2005) Study of the positive degree-day factors on the Koxkar Baqi Glacier on the south slope of Tianshan Mountains. J Glaciol Geocryol 27:337-343

Zhang Y, Liu SY, Ding YJ et al (2006) Preliminary study of mass balance on the Keqicar Baxi Glacier on the south slopes of Tianshan Mountains. J Glaciol Geocryol 28:477-484 